\title{
Inkonsistensi Pengaturan Keterwakilan Perempuan Dalam Pengisian Anggota Badan Permusyawaratan Desa
}

\author{
Abd. Latif ${ }^{1}$ \\ Universitas Trunojoyo Madura \\ abdl70369@gmail.com \\ Dr. Indah Cahyani ${ }^{2}$ \\ Universitas Trunojoyo Madura
}

\begin{abstract}
ABSTRAK
Ketertwakilan perempuan dalam pengisian anggota badan permusyawaratan desa (BPD) diatur didalam UU Nomor 6 tahun 2014 tentang Desa yakni dipasal 56 ayat 1 bahwa pengisian anggota BPD dilakukan secara demokratis selain itu peraturan pelaksananya yakni PP Nomor 43 tahun 2014 juga telah mempertegas yakni dipasal 72 ayat 1 bahwa pengisian keanggotan BPD pelaksaannya itu dilakukan dengan cara demokratis baik secara langsung, ataupun perwakilan dengan tetap terjaminnya kedaulatan rakyat. Terjadi inkonsistensi meteri muatan didalam permendagri Nomor 110 tahun 2016 tepatnya dipasal 8 aat 3 yang menyatakan bahwa pengisian keanggotaan BPD dari keterwakialn perempuan pemilihanya dilaksanakan oleh perempuan yang mempunyai hak pilih hal justru tidak sejalan dengan UU diatas nya yang menyatakan bahwa konsep demokrasi yang dipakai didalam pengisian keanggota BPD. berdasarkan isu hukum yang telah dijelas diatas maka didalam penelitian ini akan meneliti apakah pengisian keanggotaan BPD sesuai dengan konsep demokrasi? Serta apakah permendagri Nomor 110 tahun 2016 benar bertentangan dengan UU diatasnya yakni UU nomor 6 tahun 2014 dan PP nomor 43 tahun 2014? Penelitian ini merupakan penelitian normatif, dengan pendekatan perundang-undangan, konseptua dan pendekatan historis. hasil dari penelitian ini menunjukan bahwa; sebagaimana yang telah ditegaskan didalam pasal 8 ayat (3) Permendagri Nomor 110 Nomor 2016, Hal ini tidak sejalan dan tidak mencerminkan hakekat dari pada sistem demokratis dalam pemilihanya, Karena pada sejatinya sistem politik yang demokratis itu, masyarakat dewasa nya baik baik laki-laki atau pun perempuan mempunyai hak yang sama dalam pengambilan keputusan politik baik itu secara langsung ataupun perwakilan. Ditinjuau dari aspek kearifan lokal dimana perempuan dianggap orang yang berkiprah dalam sektor domestik sementara laki-laki ditempatkan dalam sektor publik, maka sangat tidak memungkinkan jika keterwakilan perempuan dalam keanggotaan BPD pemilihanya hanya dilakuakan oleh perempuan saja.
\end{abstract}

Kata kunci: Inkonsitensi, Keterwakilan Perempuan, Badan Permusyawatan Desa.

ABSTRACT

Representation of women in filling in the members of the Village Consultative Body (BPD) is regulated in Law Number 6 of 2014 concerning Villages, namely Article 56 paragraph 1 that filling in BPD members is carried out democratically. 1 that the filling of the BPD membership is carried out in a democratic way, either directly or through representation while ensuring the sovereignty of the people. There was an inconsistency of content material in Permendagri Number 110 of 2016 precisely in Article 8 Aat 3 which states that the filling of BPD membership from the representation of women in elections is carried out by women who have the right to vote. $B P D$. Based on the legal issues described above, this research will examine whether filling BPD membership is in accordance with the concept of democracy? And is the Minister of Home Affairs Number 110 of 2016 really contradicting the above laws, namely Law Number 6 of 2014 and Government Regulation Number 43 of 2014? This research is a normative research, with a statutory, conceptual and historical approach. The results of this study indicate that; as has been confirmed in article 8 paragraph (3) of the Minister of Home Affairs Regulation Number 110 Number 2016, this is not in line and does not reflect the nature of the democratic system in the election, because in essence a democratic political system, the adult community is either male or female. Even women have the same rights in making political decisions, either directly or through representatives. Judging from the aspect of local wisdom where women are considered people who take part in the domestic sector while men are placed in the public sector, it is very unlikely that women's representation in BPD membership is elected only by women.

Key words: Inconsistency, Women's Representation, Village Consultative Body. 


\section{PENDAHULUAN}

Sistem hukum terdiri dari bagianbagian yang merupakan sebuah satu kesatuan dan tentunya tidak dapat berdiri sendiri dan mengikt satu dengn yang lainnya. Dimana Disetiap sisi mempunyai nakna yang sama. Sistim hukum tak jarang mempunyai arti yang sama dengan tatahukum ${ }^{1}$. berbagai fenomina konflik hukum yang terjadi, itu semua dapat diselesaikan dengan dan didalam sistem hukum itu sendiri, oleh kerenanya maka sangat dibutuhkannya partisipansi dalam penyelenggraan sistem hukum yang baik.

Sistem hukum digolongkan menjadi 3 (tiga) golongan, yakni stuktur hukum (structure of law), substansi hukum (substance of the law), dan budaya hukum (legal culture). Masyarakat dapat mematuhi dan tidaknya terhadap hukum, itu bisa dikarenakan faktor Budaya hukum yang berupa idea, tingkah laku, harapan dan pendapat tentang hukum ${ }^{2}$. Salah satu lembaga yang penting yang ada didalam pemerintahan tatanan desa ialah Badan permusyawaratan desa (selanjutnya disebut BPD). Menurut Pasal 1 angka 4 Undang-Undang nomor 6 tahun 2014 tentang desa (selanjutnya disebut UU no 6/2014), BPD atau yang di ketahui dengan sebutan lain merupaklan kelembagaan yang fungsinya

1 Irvan Arisandi, Tata Hukum di Indonesia, Jurnal Syariah Hukum Islam Vol. 2 No 1, Oktober 2019, (Sulawesi Tenggara: Fakultas Hukum Keluarga Islam IAI Al-Mawaddah Warrahmah, 2019), hlm. 55.

2 Lawrence M. Friedman, The Legal System: A Social Science Perspective, (New York: Russel Sage Foundation, 1975), hlm. 14-15. untuk melaksanakan pemerintahan desa dimana anggotanya berisikan wakil dari penduduk Desa yang berdasarkan atas keterwakilan wilayah serta dengan ditetapkan secara demokratis. BPD itu sendiri merupakan lembaga yang merupakan perwujudan prinsip demokrasi dalam penyelenggaraan sistem pemerintahan desa sebagai unsur penyelenggara pemerintahan desa yang mempunyai fungsi untuk membahas dan menyepakati Rancangan Peraturan Desa bersama Kepala Desa; menampung dan menyalurkan aspirasi masyarakat desa; dan melakukan pengawasan kinerja Kepala Desa ${ }^{3}$. Didalam pengisian keanggotaan BPD ini harus memperhatikan adanya keterwakilan perempuan dalam anggota BPD dengan tujuan untuk menampung dan menyalurkan kepentingan atau urusan perempuan ${ }^{4}$. Artinya didalam pengisian anggota BPD pemerintah harus tidak ambigu dalam memperhatikan adanya keikut sertaan peran aktif perempuan dalam berpolitik khususnya di pemerintahan desa. dalam proses atau mekanisme pengisian keterwakilan perempuan dalam pengisian anggota BPD itu melalui sistem demokratis dimana demokratis itu sendiri merupakan sifat dari suatu negara yang menganut prinsip demokrasi baik secara langsung ataupun dengan cara perwakilan yang terpenting adalah terjaminnya kemerdekaan rohani dan keselarasan dimata hukum. Selain itu juga diatas ditegaskan bahwa adanya kata

\footnotetext{
3 Pasal 55 Undang-Undang nomor 6 tahun 2014 tentang desa

${ }^{4}$ Ibid pasal 58 ayat (1)
} 
menjamin pada hakekatnya pemerintah betulbetul mengharuskan adanya keterlibatan peran serta perempuan dalam pengisian anggota BPD ini untuk menampung dan menyalurkan kepentinganm serta aspirasi kelompok perempuan, dikarenakan perempuan juga memiliki hak yang sama didalam berperan didalam politik.

Inkonsistensi terjadi di dalam permendagri No 110/2016 dengan PP no.43/2014, dimana didalam permendagri no 110/2016 tepat nya di pasal 8 mengatur bahwa didalam pemilihan keterwakilan perempuan dalam keanggotaan BPD ini dipilih oleh perempuan warga desa yang memiliki hak pilih. pasal ini layak serta perlu untuk di kaji ulang dikarenakan didalam peraturan di atas nya, baik di dalam PP no 43/2014 ataupun UU no 6/2014, disana tidak mengatur bahwa mekanisme pengisian keterwakilan perempuan dalam anggota BPD harus di pilih oleh perempuan warga desa yang mempunyai hak pilih, dalam peraturan diatasnya menegaskan bahwa pengisian keterwakilan perempuan dalam anggota BPD itu dilaksanakan secara demokratis sedangkan sistem pemilihan yang diatur dalam permendagri no 110/2016 itu sama sekali tidak menggambarkan prinsip demokrasi. memang benar adanya di dalam PP no 43/2014 tepatnya di pasal 79 memberikan kewenangan kepada menteri untuk mengatur lebih lanjut mengenai BPD, akan tetapi tidak seharusnya menteri dalam membuat kebijakan, melebihi dari pada kewenangan yang telah diberikan oleh peraturan di atasnya.

Berdasarkan latar belakang masalah yang telah dijelaskan secara rinci diatas, penulis dapat menarik beberapa rumusan masalah sebagai inti dalam kepenulisan ini. diantaranya:

1. Apakah keanggotaan BPD sesuai dengan konsep demokrasi.?

2. Apakah keterwakilan perempuan dalam pengisian anggota BPD yang diatur dalam permendagri nomor 110 tahun 2016 bertentangan dengan PP nomor 43 tahun 2014 dan peraturan diatasnya.?

\section{METODE PENELITIAN}

Hukum Normatif merupakan suatu jenis penelitian yang ambil untuk di gunakan didalam penelitian ini, dimana Hukum Normatif ini merupakan penelitian yang dikhususkan dalam mengkaji serta menelaah terkait penerapan Kaidah-kaidah atau Normanorma yang terdapat didalam Hukum Positif. ${ }^{5}$ Hukum memandang terhadap konsep ini yakni sebagai Sistem Nomatif yang tertanam sifat mandiri didalam nya, terlepas atau tidaknya terhadap kelangsungan hidup masyarakat nyata. 6 Adapun Pendekatan yang gunakan didalam Hukum Nomatif ini yakni konsep logis positivis. Menggunakannya metode penelitian Hukum Normatif dalam penelitian ini bertujuan agar supaya penelitian dan penulisan dalam penelitianya ini didasarasi

5 Johnny Ibrahim, Teori dan Metodologi Penelitian Hukum Normatif, (Malang: Bayumedia Publishing, 2006), hlm. 295.

6 Ronny Hanitijo Soemitro, Metodologi Penelitian Hukum dan Jurimetri, (Jakarta: Ghalia Indonesia, 1998), hlm. 13-14. 
dengan keselarasan antara Teori-teori dengan metode penelitian yang dibutuhkan oleh peneliti.

Berdasarkan jenis penelitian diatas pendekatan yang penelitian yang erat kaitanya dalam skripsi ini adalah Pendekatan Perundang-Undangan (Statue Approach), Pendekatan perundang-undangan ini misalnya dilakukan dengan menelaah dan menganalisis konsistensi atau kesesuaian antara UndangUndang yang satu dengan Undang-Undang yang lainnya. Pendekatan Konseptual( Conceptual Approach), Pendekatan ini berangkat dari Pandangan-pandangan dan Dokrin-dokrin yang terus berkembang di bidang ilmu Hukum. Pendekatan Historis( Historical Approach). pendekatan ini dilakukan dengan cara menelaah dan menganalisis asal mula latar belakang dan asal perkembangan pengaturan mengenai isu hukum yang dihadapi.

Adapun teknik pengumpulan bahan hukum yang digunakan dalam penelitian ini yakni melalui metode dengan stadi pustaka; yang mana nantinya peneliti melaksanakan pencarian serta penelusuran terhadap bahan pustaka seperihal nya literatur, hasil penelitian, majalah ilmiah, buletin ilmiah, jurnal ilmiah dsb. Setelah Bahan hukum yang diperoleh atau yang dikumpulkan dalam penelitian ini baik data primer serta data sekunder maupun data tersier merupakan data yang sifatnya masih kualitaif, kemudian setelah itu data tersebut diolah dan dianalisis secara deduktif yaitu dengan berlandaskan kepada Dasar-dasar pengetahuan umum meneliti persoalan yang bersifat khusus, dari adanya analisis inilah kemudian ditarik suatu kesimpulan.

\section{HASIL DAN PEMBAHSAN}

\section{Keanggotaan BPD Dalam Perspektif Demokrasi}

\begin{abstract}
Demokratis merupakan sifat suatu negara yang menganut sistem demokrasi dalam melakukan pergantian estafed kekuasaan, khasanah dalam berfikir dan prerefomasi politic dibelahan negara sampai pada satu titik ditemukannya bahwa; dari berbagai pilihan lainnya yang sangat terbaik dalam sistem politik adalah demokrasi. 7
\end{abstract}

Hakekat makna dari pada demokrasi itu sendiri adalah sistem pemerintahan yang dimana masyarakat dewasanya turut ikut serta dalam mengambil keputusan politik dengan tetap menjamin tercapainya hak politik warga negara, baik secara langsung atau pun perwakilan, hal ini dikuatkan dengan pendapatnya beberapa para ahli tentang pengertian Demokrasi itu sendiri diantara nya pendapatnya dari "W.A Bonger yang telah mendefnisikan demokrasi adalah sebagai bentuk sistem pemerintahan dari suatu kesatuan hidup yang telah memerintahkan diri sendiri, $8 "$ artinya sebagia besar anggotanya turut ikut serta

7 Ni'matul Huda, Ilmu Negara, (Jakarta: Raja Grafindo, 2014), hlm. 196.

8 Eddy Purnama, Negara Kedaulatan Rakyat, (Jakarata: Nusamedia, 2007), hlm. 4. 
dalam mengambil bagian atau keputusan politik, dengan terjaminnya suatu kemerdekaan rohani dan keselarasan dimata hukum. Selain itu ada pendapatnya dari C.F. Stronk. Juga memberikan definisi terkait Demokrasi yakni sebagai suatu sistem pemerintahan yang mayoritas anggota dewasa dari masyarakat politik juga ikut serta baik itu melalui sistem perwakilan dengan adanya jaminan bahwa pemerintah harusnya bertanggung jawap penuh atas tindakantindakannya kepada mayoritas itu 9 . Dapat diambil pemahaman bahwa, negara yang menganut sistem demokrasi sepatutnya didasari adanya sistem perwakilan, yang meskipun perwakilan tetapi tetap tercapainya jaminan kedaualatan rakyat dalam terlaksana.

Alamuddin juga telah memberikan pandangannya terkait penjelasan Demokrasi yang sebenarnya yakni suatu seperangkat gagasan dan prinsip tentang kebebasan, serta juga mencangkup seperangkat praktik dan prosedor yang tercipta melalui sejarah Panjang dan berlika-liku 10 . Artinya demokrasi disebut juga sebagai suatu kelembagaan dari kebebasan yang telah teruji oleh zaman, Oleh Karna nya hak asasi dan persamaan dihadapan hukum itu wajib dinikmati oleh segenap rakyat

\section{${ }^{9}$ Ibid}

10 Muslim Mufti dan Didah Durrotun Naafisah, Teori-Teori Demokrasi, (Jakarta: Pustaka Setia, 2013), hlm. 115. khusunya didalam pengambilan keputusan politik.

Sedangkan menurutnya Henry B. Mayo yang diikuti oleh Ni'matul Huda di dalam bukunya Hukum Tata Negara Indonesia, juga memberikan defenisi terhadap demokrasi sebagai sistem politik sebagai berikut11: "Sistem politik yang demokratis ialah dimana kebijaksanaan umum ditentukan atas dasar mayoritas oleh wakil-wakil yang diawasi secara efektif oleh rakyat dalam pemilihanpemilihan berkala yang didasarkan atas prinsip kesamaan politik dan diselenggarakan dalam suatu terjaminnya kebebasan politik" Oleh karenya maka sistem demokrasi di dalam pengisian keanggotaan BPD seharusnya tidak membedakan trans jender dimana semua masyarakat dewasa yang mempunyai hak kebebasan dalam pengambilan keputusan politik baik baik lak-laki maupun prempuan terdapat hak-hak yang sama di dalam nya untuk turut ikut serta di dalam menentukan keputusan politik, baik secara langsung ataupun tidak langsung (perwakilan) yang terpenting adalah hak hak dalam berpolitik dapat dinikmati sepenuhnya oleh masyarakat, sehingga nantinya dapat dikatakan secara pantas dan tegas bahwa demokratis menjadi sistem yang sangat ideal dalam pengisian

11 Ni'matul Huda, Hukum Tata Negara Indonesia, (Jakarta: PT Raja Grafindo Persada, 2004), hlm. 266. 
keanggotaan BPD demi terlaksananya hak-hak kebebasan masyarakat desa.

Didalam pengisian keanggotaan BPD terdapat dua keterwakilan: yang pertama adalah keterwakilan wilayah dan yang kedua keterwakilan perempuan, hal ini ditegaskan didalam pasal 6 permendagri no 110/2016 tentang BPD. dimana keterwakilan perempuan ini pemilihanya hanya dilakukan oleh prempuan saja yang miliki hak memilih 12 ; artinya laki-laki tidak boleh ikut serta dalam pemilihan kterwakilan prempuan didalam pengisian eanggota BPD. hal ini jika disingkronkan dengan konsep demokrasi yang sesuangguhnya, maka sistem pemilihan tentang keterwakilan perempuan dalam pengisian keanggotaan BPD ini tidak mencerminkan nilai-nilai demokrasi yang sesungguhnya.

Hal ini dikuatkan oleh kutipan dari Robert. A. Dahl, yang di ikuti oleh Muntoha dalam jurnalnya yang berjudul Demokrasi dan Negara Hukum menyatakan bahwa Demokrasi sebagai suatu gagasan politik di dalamnya terkandung 5 (lima) kriteria salah satunya adalah :13

12 Pasal 8 ayat (3) permendagri 110 tahun 2016

13 Robert A. Dahl, Dilema Demokrasi Pluralis: Antara Otonomi dan Kontrol, (Rajawali Press, Jakarta, 1985), hlm. $19-20$.
a. Persamaan hak pilih dalam menentukan keputusan kolektif yang mengikat;
b. Partisipasi efektif, yaitu
kesempatan yang sama bagi
semua warga negara dalam proses pembuatan keputusan secara kolektif;
c. Pembeberan kebenaran, yaitu adanya peluang yang sama bagi setiap orang untuk memberikan penilaian terhadap jalannya proses politik dan pemerintahan secara logis;

\section{Analisis Keterwakilan Perempuan Dalam Pengisian Keanggotaan BPD.}

Keterwakilan perempuan dalam keanggotan BPD yang diatur didalam UU No 06/2014 tepatnya di 58 ayat (1) disana menegaskan bahwa kenggotan Badan permusyawatan desa berisikan jumlah gasal yakni paling sedikitnya 5 (lima) dan paling banyaknya 9 (sembilan) orang yang didalam jumlah tersebut harus memperhatikan adanya perempuan dalam anggota BPD, di perjelas kembali oleh peraturan pelaksana UU no 6/2014 yakni PP no 43/2014 tepatnya dipasal 72 ayat (1) mempertegas kembali bahwa: didalam pengisian keanggota BPD harus menjamin adanya keterwakilan perempuan, guna menampung serta penyampaikan aspirasi atau permasalahan kelompok perempuan 
didesa, sehingga kelompok perempuan didesa mempunyai tempat untuk menyampai aspirasinya.

Keterwakilan perempuan dalam keanggotaan BPD lebih mendapatkan kepastian hukum, dengan hadirnya permendagri nomor 110/2016. Pasal nya didalam permengari memberikan jatah 1 orang perempuan untuk menjadi anggota BPD hal ini ditegas dalam pasal 8 ayat 1 permendagri nomor 110 tahun 2016.

\section{Keterwakilan Perempuan Dalam Keanggotaan Bpd Ditinjau Dari Aspek Khirarki Peraturan Perundang- Undangan}

Khirarki peraturan perundangundangan yakni suatu sistem hukum yang terbentuk dari pola anak tangga dengan kaidah berjenjang, 14 maksud dari pada khirarki peraturan perundangundangan ini ialah peraturan diatas merupakan sumber lahirnya peraturan dibawahnya dan seterusnya, sedangkan peraturan dibawahnya merupakan norma penafsiran yang lebih rinci serta kompleks dari norma diatas nya.

Norma hukum itu sendiri memiliki masa berlaku (rechkracht) yang relatif, karena masa berlakunya suatu norma itu tergantung pada norma hukum yang diatasnya, sehingga apabila nurma hukum yang berada diatasnya dicabut atau dihapus, maka norma-norma hukum yang berada dibawahnya juga tercabut atau terhapus pula. 15

Jika disingkronkan dengan permasalahan didalam penelitian ini dimana keterwakilan perempuan dalam pengisian keanggotaan BPD ini pemilihannya hanya dilakukan oleh perempuan saja, sebagaimana yang diatu dipasal 8 ayat (3) Permendagri No 110 Tahun 2016 tentang BPD. Hal ini justru tidak mencerminkan hakekat dari pada demokrasi sehingga hal ini tidak sejalan atau bisa dikatakan bertentangan dengan peraturan perundang-undangan diatasnya yakni UU no 06/2014 tepatnya di pasal 56 ayat (1) yang menegaskan bahwa pengisian keanggotaan BPD ini dilakukan dengan cara demokratis, selain itu juga didalam peraturan pelaksanaannya yakni PP no 43 tahun 2014 tepatnya dipasal 72 ayat (1) juga menegaskan bahwa dalam pengisian keanggotaan BPD pemilihanya dilaksanakan dengan cara demokratis, baik melalui proses pemilihan secara langsung ataupun musyawarah perwakilan.

14 Jimly Asshiddiqie, dan Safa'at, M. Ali, Theory Hans KelsenTentang Hukum, Cet I, (Sekretariat Jendreral \& Kepaniteraan Makamah Konstitusi RI, Jakarta, 2006), hlm. 110.

15 Farida, Maria, Ilmu PerundangUndangan, (Yogyakarta: Kanisius, 1998), hlm. 25 . 


\section{Keterwakilan Perempuan Dalam} Keanggotaan BPD ditinjau Dari Aspek Demokrasi Dan Negara Hukum

\begin{abstract}
Jimly Asshiddiqie berpendapat bahwa didalam konsep demokrasi, kedaulatan ditangan rakyat, sedangkan didalam konsepsi negara hukum, hukum merupakan prinsip yang terkandung didalam negara hukum. 16 Sehingga prinsip-prtinsip demokrasi dan negara hukum diaplikasikan dengan cara ber iringan yaitu sebagai 1 (satu) mata uang yang mempunyai 2 (dua) wajah, Paham negara hukum yang demikian dikenal dengan sebutan negara hukum yang demokratis democratische rechtsstaat atau dalam bentuk konstitusional disebut
\end{abstract} constitutional democracy.

Konsep demokrasi dan negara hukum juga diperkuat oleh hadirnya pendapat Mahfud MD yang menyatakan didalam bukunya yang berjudul Dasar \& Struktur Ketatanegaraan Indonesia. Bahwa satu asas yang merupakan pasangan logis dari asas demokrasi adalah asas negara hukum, Alasannya, jika satu suatu negara diselenggarakan dari, oleh dan untuk rakyat, maka untuk menghindari Hak rakyat dari kesewenang-wenangan dan untuk

16 Jimly Asshiddiqie, Menuju Negara Hukum yang Demokratis, Sekretariat Jenderal dan Kepaniteraan Mahkamah Konstiusi, (Jakarta: Konstitusi Press, 2008), hlm. 690. melaksanakan kehendak rakyat bagi pemegang kekuasaan negara haruslah segala tindakannya dibatasi atau dikontrol oleh hukum. 17

Negara indoensia menyatakan bahwa dirinya sebagai negara hukum hal ini sebagaimana yang telah ditegaskan didalam Pasal 1 ayat (3) UUD 1945; Negara Indonesia adalah negara hukum. itu artinya maka memang sangat ideal apabila terkait keterwakilan perempuan dalam pengisian keanggotaan BPD, pemilihannya dilakukan secara demokrasi baik secara langsung ataupun secara perwakilan.

\section{Keterwakilan Perempuan Dalam Keanggotaan BPD Ditinjau Dari Aspek Kearifan Lokal}

Terkait kearifan lokal Alfian memberikan pengertian bahwa Kearifan lokal diartikan sebagai cara pandangan hidup dan pengetahuan serta sebagai strategi kehidupan yang berwujud aktifitas yang dilakukan oleh masyarakat lokal dalam memenuhi kebutuhan mereka. 18 Berdasarkan pendapat itu dapat diartikan bahwa kearifan lokal merupakan adat dan kebiasan yang telah

17 Mahfud MD, Dasar \& Struktur Ketatanegaraan Indonesia, (Jakarta: Rineka Cipta, 2001), hlm. 85.

18 Alfian, Magdalia. Potensi Kearifan lokal dalam Pembentukan Jati Diri dan Karakter Bangsa, (Jogyakarta: gramatika, 2013), hlm. 428. 
mentradisi dilakukan oleh sekelompok masyarakat secara turun-temurun hingga saat ini masih dipertahankan keberadaannya oleh masyarakat hukum adat di daerah tertentu.

Budaya masyarakat Jawa, banyak istilah-istilah yang mendudukkan posisi perempuan lebih rendah dari pada lakilaki. Dan istilah itu sudah tertanam dalam hati masyarakat. Sebagai contoh; dalam istilah jawa ada menyebutkan bahwa istri sebagai kanca wingking yang artinya teman belakang, sebagai teman dalam mengelola urusan rumah tangga, Istilah lain yang melekat pada diri seorang perempuan yaitu dapur, pupur, kasur, sumur. Citra peran dan status sebagai perempuan telah diciptakan oleh budaya.

Implikasi dari konsep dan common sense tentang pemosisian yang tidak seimbang telah menjadi kekuatan didalam pemisahan sektor kehidupan didalam sektor domestik dan sektor publik, dimana perempuan dianggap orang yang berkiprah dalam sektor domestik sementara laki-laki ditempatkan dalam sektor publik. Dengan adanya kearifan lokal yang melakat serta terus berkembang ditengah-tengah masyarakat, maka sangat tidak memungkinkan jika keterwakilan perempuan dalam keanggotaan BPD pemilihanya hanya dilakuakan oleh perempuan yang mempunyai hak memilih saja, sebagaimana yang telah ditegaskan didalam pasal 8 ayat (3) permendagri no $110 / 2016$.

\section{Keterwakilan Perempuan Dalam} Keanggotaan BPD Dalam Perspektif Hak*Asasi*Manusia

Salah satu prinsipnya menurutnya Julius Stahl, konsep negara hukum yang disebutkan dengan istilah rechtsstaat adalah pengakuan dan penghormatan terhadap hak asasi manusia ${ }^{19}$, Negara Indonesia dalam menjamin hakhak warga negaranya khususnya hak sipil dan politik telah memuat HAM tersebut kedalam Undang- Undang Dasar tahun1945. Yakni dipasal 27 ayat 1, pasal $28 \mathrm{D}$ ayat 3 , pasal $23 \mathrm{E}$ ayat 3 . Sifat HAM terbagi menjadi dari 2 (dua) garis besar yaitu universal, dan partikular. Adapun yang universal terbelah lagi menjadi dua perspektif turunan, yaitu universal absolut dan universal relatif. Sedangkan sifat HAM yang partikular juga dapat diturunkan lagi ke dua pandangan turunan, yaitu partikularisme absolut dan relatif. 20

19 Sri Rejeki Hartomo, Kapita Selekta Hukum Ekonomi, (Bandung, Mandar Maju, 2000), hlm, 32

20 Halili, Hak Asasi Manusia: dari Teori ke Pedagogi, Universitas Negeri Yogyakarta, 2005, hlm. 8, diakses melalui http://staff.uny.ac.id/sites/default/files/pendidi kan/halili-spdma/buku-ajar-pendidikan-hambab-awal-dan-bab-i.pdf pada 27 0ktober 2021. 
Pemilihan

$$
\text { Keterwakilan }
$$

perempuan dalam pengisian

keanggotaan BPD, merupakan HAM

yang bersifat Partikularisme Relatif

dimana permasahan ini merupakan

permasalahan yang ruang lingkup

nasional, dan permasalahn ini tumbuh dan berkembang dari nilai-nilai budaya yang sudah melekat dalam diri masyarakat desa, yang memposisikan perempuan sangat jarang untuk ikut serta didalam pengambilan leputusan politik, akan tetapi tetap tidak boleh mengurangi atau berpegang teguh pada nilai-nilai HAM yang bersifat universal. Apabila ditinjau dari kaca mata derogable rights dan neo derogable rights pemiliha keterwakilan perempuan dalam pengisian anggota BPD merupakan HAM derogable rights dimana hak ini dapat dikurangi. hak ini dapat dilakukan apabila sebanding dengan ancaman yang mengganggu keamanan nasional atau situasi darurat yang dihadapi dan tidak bersifat diskriminatif terhadap ras dan etnis. ${ }^{21}$ Artinya pencabutan hak ini harus dilakukan terhadap kemungkinan terjadinya gangguan keamanan nasional yang didasarkan kepada tindakannya bukan karena warna kulit, ataupun etnis.

Adapun penetapan kouta dari

21 Osgar S. Matompo. Pembatasan Terhadap Hak Asasi Manusia Dalam Prespektif Keadaan Darurat. Jurnal Mediahukum Vol. 21 No.1 Juni 2014. Hal 59.
Keterwakilan perempuan dalam Keanggotaan BPD yang diberikan jatah 1 kursi untuk menjadi anggota BPD, merupakan salah satu perinsip atau bentuk pelaksanaan affirmatif action, yang bertujuan untuk mencapai kesetaraan antara laki-laki dan perempuan didalam hak berpolitik, baik memilih atau dipilih agar tidak terjadinya deskriminasi. Sistem affirmative action juga diaplikasikan didalam lembaga, legislatif, eksekutif, yudikatif $^{22}$, yang dimana terjaminya keterwakilan perempuan didalamnya, yang pimilihanya dilakukan baik lakilaki atau pun perempuan sama ikut serta didalam pemilihanya baik legislatif, eksukutif maupun dilembaga yudikatif. Lantas pengapa hanya di BPD keterwakilan perempuan pemilihanya hanya dipilih oleh perempuan saja.

\section{KESIMPULAN}

Hakekat makna dari pada demokrasi beberapa para ahli telah memberikan pendapatnya terkait defini demokrasi yang sebenarnya, diantranya ada pendapatnya dari hendry B. mayo, dan W.A bonger serta pendapatnya jamaluddun. Yang dapat diambil benang merah bahwa hakekat makna demokrasi itu adalah didalam pengambulan

22 Achie Sudiarti Luhulima, Bahan Ajar Tentang Hak Perempuan: UU No. 7 tahun 1984 Pengesahan Konvensi Mengenai Penghapusan Segala Bentuk Diskriminasi Terhadap Wanita, (Buku Obor, Jakarta, 2007), hal. 137 
kebijakan umum ditentukan secara langsung oleh rakyat baik laki-laki ataupun perempuan tanmpa membedakan trans jender atau perwakilan yang diawasi secara efektif oleh rakyat dengan tetap berdasarkan atas prinsip kesamaan politik serta diselemnggrakan dalam suatu terjaminya kebebasan politik. Oleh karenya maka jika disingkronkan dengan konsep pemilihan keterwakilan perempuan dalam pengisian anggota $\mathrm{BP}$, yang diatur didalam permendagri nomor 110 tahun 2016 tepatnya dipasal 8 ayat (3) hal itu justru tidak mencerminkan makna hakekat yang sesungguhya dari demokrasi.

Inkonsistensi terjadi didalam permendagri no 110/2016 tentang BPD tepatnya di pasal 8 ayat (3) disana tidak mencerminkan sitem demokratis dalam pemilihan keanggotaan BPD dari keterwakilan perempuan. Ditinjau dari aspek sistem hukum yakni khirarki peraturan perundang-undngan maka seharus nya pasal 8 ayat (3) permendagri no 110/2016 tidak boleh bertentangan dengan peraturan diatasnya yakni UU no 6/2014 dan PP no 43/2014. Pasalnya didalam peraturan diatanya menegaskan bahwa sistem pemilihan dari pada keanggotaan BPD itu dilakukan secara demokratis. Didalam konteks hukum islam perempuan diperbolehkan perperan dibidang publik tidak nya dibidang domestik, hak ini bersifat derogable rights (yang dapat dikurangi) yang termasuk jenis hak partikularisme relatif. Indonesia dikenal negara hukum maka harus menjadikan demokrasi sebagai suatu sistem didalam pemerintahanya sebab kedua konsep ini (demokrasi dan negara hukum) tidak bisa dipisahkan. dikarenakan jika satu suatu negara diselenggarakan dari, oleh dan untuk rakyat, maka untuk menghindari Hak rakyat dari kesewenang-wenangan dan untuk melaksanakan kehendak rakyat bagi pemegang kekuasaan negara haruslah segala tindakannya dibatasi atau dikontrol oleh hukum hal ini sejalan dengan pendapatnya jimly Asshiddiqie dan diperkuat oleh pendapatnya mahfud MD dalam bukunya.

Ditinjuau dari aspek kearifan lokal, Implikasi dari konsep dan common sense tentang pemosisian yang tidak seimbang telah menjadi kekuatan didalam pemisahan sektor kehidupan didalam sektor domestik dan sektor publik, dimana perempuan dianggap orang yang berkiprah dalam sektor domestik sementara laki-laki ditempatkan dalam sektor publik, maka sangat tidak memungkinkan jika keterwakilan perempuan dalam keanggotaan BPD pemilihanya hanya dilakuakan oleh perempuan.

\section{SARAN}

Demi tercapainya suatu sistem demokratis didalam pengisian keanggotaan BPD dari keterwakilan perempuan yang diatur didalam pasal 8 ayat (3) permendagri no 110/2016, maka sistem pemilihanya harus melibatkan peran serta dari semua masyrakat dewasa tanpa membedakan trans jender baik laki-laki ataupun perempuan, untuk turut ikut serta dalam pengambilan keputusan politik khusunya pemilihan keterwakilan perempuan dalam keanggotaan BPD, Dalam Hal ini 
bertujuan demi tercapainya hak-hak

kedaulatan rakyat. Serta masyarakat bisa

menikmati secara utuh hak kebebasan

berpolitik.

Agar tidak terjadinya inkonsistensi di pasal 8 ayat (3) peremendagri no 110/2016 dengan peraturan diatanya, maka disarankan untuk dilakukan judicial review atau diujikan kembali pasal tersebut ke mahkamah agung, dengan maksud dan tujuan untuk mengubah konsep atau mekanisme pengisian keterwakilan perempuan dalam keanggotaan BPD yang sesuai dengan sistem demokrasi yang sebenarnya, sebagaimana yang telah diperintahkan oleh peraturan diatasnya yakni UU no 6/2014 pasal 56 ayat (1) dan peraturan pelaksaanya yakni PP no 43/2014. 


\section{DAFTAR PUSTAKA}

Buku:

Johnny Ibrahim, Teori dan Metodologi

Penelitian Hukum Normatif, Malang:

Bayumedia Publishing, 2006.

Ronny Hanitijo Soemitro, Metodologi

Penelitian Hukum dan Jurimetri,

Jakarta: Ghalia Indonesia, 1998.

Ni'matul Huda, Ilmu Negara, jakarta: Raja

Grafindo, 2014.

Eddy Purnama, Negara Kedaulatan Rakyat,

Jakarata: Nusamedia, 2007.

Muslim Mufti dan Didah Durrotun Naafisah,

Teori-Teori Demokrasi, Jakarta:

Pustaka Setia, 2013.

Ni'matul Huda, Hukum Tata Negara

Indonesia, jakarta: PT Raja Grafindo Persada, 2004.

Robert A. Dahl, Dilema Demokrasi Pluralis:

Antara Otonomi dan Kontrol, Rajawali

Press, Jakarta, 1985.

Jimly Asshiddiqie, dan Safa'at, M. Ali,

Theory Hans KelsenTentang Hukum,

Cet I, Sekretariat Jendreral \&

Kepaniteraan Makamah Konstitusi RI,

Jakarta, 2006.

Farida, Maria, Ilmu Perundang-Undangan,

Yogyakarta: Kanisius, 1998.

Jimly Asshiddiqie, Menuju Negara Hukum

yang Demokratis, Sekretariat Jenderal

dan Kepaniteraan Mahkamah

Konstiusi, Jakarta: Konstitusi Press, 2008.

Mahfud MD, Dasar \& Struktur

Ketatanegaraan Indonesia, Jakarta:

Rineka Cipta, 2001.
Alfian, Magdalia. Potensi Kearifan lokal dalam Pembentukan Jati Diri dan Karakter Bangsa, Jogyakarta: gramatika, 2013.

Sri Rejeki Hartomo, Kapita Selekta Hukum Ekonomi, Bandung, Mandar Maju, 2000.

Achie Sudiarti Luhulima, Bahan Ajar Tentang Hak Perempuan: UU No. 7 tahun 1984

Pengesahan Konvensi Mengenai Penghapusan Segala Bentuk Diskriminasi Terhadap Wanita, Buku Obor, Jakarta, 2007.

\section{JURNAL:}

Irvan Arisandi, Tata Hukum di Indonesia, Jurnal Syariah Hukum Islam Vol. 2 No 1, Oktober 2019, Sulawesi Tenggara: Fakultas Hukum Keluarga Islam IAI Al-Mawaddah Warrahmah, 2019.

Lawrence M. Friedman, the Legal System: A Social Science Perspective, New York: Russel Sage Foundation, 1975.

Halili, Hak Asasi Manusia: dari Teori ke Pedagogi, Universitas Negeri Yogyakarta, 2005, hlm. 8, diakses melalui

http://staff.uny.ac.id/sites/default/files/p endidikan/halili-spdma/buku-ajarpendidikan-ham-bab-awal-dan-babi.pdf pada 27 0ktober 2021.

Osgar S. Matompo. Pembatasan Terhadap Hak Asasi Manusia Dalam Prespektif Keadaan Darurat. Jurnal Mediahukum Vol. 21 No.1 Juni 2014. 


\section{Peraturan perundang-undangan:}

Undang- Undang Dasar Negara Republik

Indonesia Tahun 1945

Undang-Undang Nomor 39 Tahun 1999

Tentang Hak Asasi Manusia

Undang- Undang Nomor 06 Tahun 2014

Tentang Desa

Peraturan Pemerintah Nomor 43 Tahun 2014

Tentang Pelaksanaan Undang- Undang

Nomor 06 Tahun 2014 Tentang Desa

Peraturan Menteri Dalam Negeri

(Permendagri) Nomor 110 Tahun 2016

Amandemen UUD Tahun 1945,

Jurisprudentie, Vol. 3 Nomor 2.

Website tanpa autor

Dewan Perwakilan Rakyat, "Parlemen

Remaja”, dikutip dari

http://www.dpr.go.id/parlemen-

remaja/index diakses pada 8 mei 2020 jam. 01:46. 